DOI: https://doi.org/10.32689/2618-0065-2020-2(4)-300-309

Романенко Свген Олександрович, доктор наук 3 державного управління, професор, Заслужений юрист України, Президент Всеукраїнської асамблеї докторів наук з державного управління, Проректор, Міжрегіональна Академія управління персоналом, 03039, м. Київ, вул. Фрометівська, 2, тел.: (044) 264-52-54, e-mail: poboss1978@gmail.com, https//orcid.org/0000-00032285-0543

\title{
В УКРАЇНІ З’ЯВИТЬСЯ НОВЕ ПЕНСІЙНЕ ВІДОМСТВО
}

Анотація. Реформування української економіки, а саме перехід ії від планової, централізованої, до ринкової і такої, що виступає в світі в якості повноцінної функціонуючої системи, передбачає створення в ній ряду ефективних механізмів соціального захисту громадян. В цьому контексті, найважливішим завданням, що стоїть перед державою $є$ питання пенсійного забезпечення громадян. Протягом останніх 30 років у багатьох країнах світу розпочалися соціальні реформи, складовою яких е реформування пенсійних систем. Метою соціальних та пенсійних реформ е підвищення ефективності державного соціального захисту і соціального страхування населення, у тому числі, забезпечення фінансової стабільності фондів обов'язкового соціального страхування та пенсійних систем. Останнє необхідно для захисту майбутніх пенсіонерів від стрімкого зменшення розміру державних пенсій у майбутньому.

Час, коли держава несла повну відповідальність за вирішення практично всіх соціальних проблем своїх громадян, минув. У результаті проведення зазначених вище реформ у країнах з'являються нові види як державних, так i недержавних, але публічних фондів. Це - фонди обов'язкового соціального страхування населення (які, за своєю економічною природою, є так званими "солідарними" фондами) та накопичувальні пенсійні фонди, (які за своєю економічною природою, є так званими "накопичувальними" фондами).

Необхідність ефективного регулювання відносин щодо утворення, управління, розподілу та використання коштів нових видів публічних фондів вимагає чіткого вирішення багатьох практичних та теоретичних проблем, а також створення відповідного нового законодавства.

Зазначено, що для відновлення належного рівня пенсійного забезпечення в Україні необхідним $\epsilon$ впровадження обов'язкового накопичувального пенсійного забезпечення як додаткового елемента пенсійної системи (так званого другого рівня), 3 метою формування пенсійних накопичень та збільшення сукупного коефіцієнта заміщення як головного 
індикатора достатності пенсійних виплат.

Ключові слова: пенсійне відомство, механізми соціального захисту громадян, накопичувальні пенсійні фонди, соціальне страхування населення.

Romanenko Yevhen Oleksandrovych, Doctor of Science in Public Administration, Professor, Honored Lawyer of Ukraine, President of the Ukrainian Assembly of Doctors of Science in public administration, vice-rector, Interregional Academy of Personnel Management, 03039, Kyiv, Str. Frometivska, 2, tel.: (044) 264-52-54, e-mail: poboss1978@gmail.com, https//orcid.org/0000-0003-2285-0543

\section{A NEW PENSION AGENCY WILL EMERGE IN UKRAINE}

Abstract. The reform of the Ukrainian economy, namely its transition from a planned, centralized, to a market economy and one that acts as a fully functioning functioning system in the world, requires the creation of a number of effective mechanisms of social protection for its citizens. In this context, the most important task facing the state is the issue of pension provision for citizens. In the last 30 years, social reforms have begun in many countries of the world, which are part of the reform of pension systems. The purpose of social and pension reforms is to increase the effectiveness of public social protection and social insurance, including ensuring the financial stability of compulsory social security funds and pension systems. The latter is necessary to protect future retirees from the rapid reduction of public pensions in the future.

The time when the state was fully responsible for solving virtually all social problems of its citizens has passed. As a result of the above-mentioned reforms, new types of state and non-state but public funds are emerging in the countries. These are compulsory social insurance funds of the population (which by their economic nature are so-called "solidarity" funds) and accumulative pension funds (which by their economic nature are so-called "savings" funds).

The need for effective regulation of relations regarding the formation, management, distribution and use of funds of new types of public funds requires clear resolution of many practical and theoretical problems, as well as the creation of appropriate new legislation.

It is noted that in order to restore an adequate level of pension provision in Ukraine, it is necessary to introduce a mandatory funded pension provision as an additional element of the pension system (the so-called second level), in order to form pension savings and increase the aggregate replacement rate as the main indicator of adequacy of pension payments.

Keywords: pension agency, mechanisms of social protection of citizens, accumulative pension funds, social insurance of the population 
Постановка проблеми. Впродовж останніх 10 років в Україні широко обговорюються проблеми реформування системи загальнообов'язкового державного соціального страхування громадян взагалі та пенсійної системи, як iï складової, зокрема.[1] Перші важливі кроки на шляху реалізації цих реформ були зроблені в 1998-2001 роках, коли Україна прийняла Основи законодавства України про загальнообов'язкове державне пенсійне страхування.[2] Відповідно до цих законів в Україні, як і в інших країнах Європи, з'явився новий вид публічних фондів - солідарні фонди загальнообов'язкового державного соціального страхування, які, за своїм правовим статусом, не є державними чи комунальними фондами, а також не $\epsilon$ органами державної влади.

Система пенсійного забезпечення фактично відображає ставлення держави до тих громадян, які відпрацювали на неї більшу частину свого життя. Торік, на дванадцятому році незалежності, в Україні розпочато практичну реалізацію пенсійної реформи, що створює кожному громадянину більше можливостей щодо самостійного вибору і прийняття рішення відносно того, яку пенсію він отримуватиме в майбутньому. Для цього запроваджується трирівнева страхова пенсійна система, де закладено основні демократичні принципи. А це означає, що держава, гарантуючи певний рівень матеріального забезпечення в старості, частково перекладає відповідальність за це і на кожного з нас, одночасно даючи нам і право вибору.

Трирівневі пенсійні системи сьогодні запроваджуються майже всіма країнами світу, що здійснюють реформування пенсійних систем. Так, наприклад, серед країн Західної та Східної Європи трирівнева пенсійна система запроваджена в Угорщині в 1998 р., у Польщі - у 1999 р., у Латвії - у 2001 році, в Естонії, Болгарії та Хорватії - у 2002 р., у Росії - у 2002 р. Казахстан у 1997-1998 роках здійснив найбільш радикальну пенсійну реформу.

Для відновлення належного рівня пенсійного забезпечення в Україні необхідним $\epsilon$ впровадження обов'язкового накопичувального пенсійного забезпечення як додаткового елемента пенсійної системи (так званого другого рівня), з метою формування пенсійних накопичень та збільшення сукупного коефіцієнта заміщення як головного індикатора достатності пенсійних виплат.

Аналіз останніх досліджень і публікацій. Важливі аспекти формування та розвитку сучасної пенсійної системи висвітлюються такими українськими ученими як І.Динь, Б.Зайчук, Б.Надточий, А.Нечай, В. Оверчук, В.Яценко. Однак впровадження обов'язкового накопичувального пенсійного забезпечення тільки планується, тому питання управління цим процесом поки що не систематизовані і розроблені не в повному обсязі.

Мета статті - дослідження особливостей та механізмів державного управління впровадженням обов'язкового накопичувального пенсійного забезпечення в умовах кризи чинної моделі пенсійного забезпечення в Україні. 
Виклад основного матеріалу. Останні події новітньої епохи, активна громадянська позиція більшості українського народу привели до того, що Україна отримала унікальний історичний шанс поставити владу на службу кожному громадянину, збудувати справедливу i заможну європейську державу, яку шанують і цінують ії власні громадяни, і до якої з повагою ставляться у світі.

Світоглядний конфлікт між суспільством та владою, між інтересами громадян і реальними діями владних фінансово-політичних груп набув антагоністичних форм. Закритість інститутів влади від громадського контролю, корпоративність у прийнятті нею рішень породили в людей недовіру до влади. Офіційно деклароване зростання валового внутрішнього продукту не супроводжувалося адекватним зростанням реальних доходів громадян. Внаслідок непродуманої урядової політики в соціальній сфері, вперше за останні роки, Україна вступила у новий фінансовий рік із загрозливим дефіцитом бюджету Пенсійного фонду.

Стратегічна мета нового Уряду - досягнення нової якості життя громадян, запровадження соціальних, економічних та демократичних європейських стандартів життєдіяльності людини, суспільства та держави. Необхідно докорінно змінити філософію влади, що склалася впродовж останніх років. Відтепер влада повинна служити людині, а не люди працюватимуть в інтересах можновладців. Соціально-економічні орієнтири нового Уряду - щорічне зростання реальної заробітної плати, пенсій та інших соціальних виплат.

Головною метою удосконалення системи соціального захисту населення $\epsilon$ розв’язання проблеми бідності, підвищення якості соціальних послуг для наближення їх до європейського рівня та розширення кола надавачів таких послуг. Перевагу повинні мати соціально незахищені громадяни похилого віку, малозабезпечені сім'ї, інваліди та сім’ї з дітьми.

У демократичному суспільстві з ринковою економікою державна влада не повинна брати на себе вирішення матеріальних проблем своїх громадян, їх пенсійні питання, а зобов'язана створювати умови, за яких люди зможуть самостійно, відповідно до своїх можливостей та бажань, їх розв’язувати.

Система пенсійного забезпечення в Україні складається з трьох рівнів.

Перший рівень - солідарна система загальнообов’язкового державного пенсійного страхування (далі - солідарна система), що базується на засадах солідарності і субсидування та здійснення виплати пенсій і надання соціальних послуг за рахунок коштів Пенсійного фонду.

Другий рівень - накопичувальна система загальнообов'язкового державного пенсійного страхування (далі - накопичувальна система пенсійного страхування), що базується на засадах накопичення коштів застрахованих осіб у Накопичувальному фонді, або у відповідних недержавних пенсійних фондах - суб’єктах другого рівня системи пенсійного забезпечення 
та здійснення фінансування витрат на оплату договорів страхування довічних пенсій і одноразових виплат на умовах та в порядку, передбачених Законом.

Третій рівень - система недержавного пенсійного забезпечення, що базується на засадах добровільної участі громадян, роботодавців та їх об’єднань у формуванні пенсійних накопичень 3 метою отримання громадянами пенсійних виплат на умовах та в порядку, передбачених законодавством про недержавне пенсійне забезпечення.

На даний час одним із найважливіших пріоритетів економічної політики держави є розвиток системи пенсійного забезпечення в Україні. Зазначене обумовлено наступним.

На 01 січня 2018 р. в Україні налічувалося 11,7 млн пенсіонерів $(27,8 \%$ загальної чисельності населення), серед яких 2,6 млн - особи з інвалідністю, понад 1 млн. - перебувають у складних життєвих обставинах, 0,8 млн. ліквідатори та потерпілі від Чорнобильської катастрофи, 0,6 млн. - ветерани війни [1].

Чисельність осіб віком 60 років і старше становила 9,7 млн осіб, або $22,9 \%$ загальної чисельності населення. На 100 осіб віком 60 років і старше припадало 79 дітей віком до 18 років і 257 осіб віком 18-59 років [2].

За даними ООН, Україна входить в топ-15 країн світу з найшвидшими темпами скорочення населення. Причому у найближчі десятиріччя скорочення населення відбуватиметься майже винятково за рахунок населення працездатного віку. За умови збереження поточних показників народжуваності, смертності та міграцій, ООН прогнозує зменшення чисельності населення України до 2050 р. на $28 \%$, водночас частка осіб віком 60 років і старше зросте до $32 \%$. Середній варіант прогнозу передбачає поступове підвищення сумарного коефіцієнту народжуваності до 1,8 дитини на 1 жінку у 2050 p. і зростання очікуваної тривалості життя в середньому на 5 років; за таких умов населення скоротиться на $18 \%$, а рівень старіння зросте до 34\%. Співвідношення між чисельністю населення пенсійного і працездатного віку зросте майже вдвічі. Демографічні зміни в Україні загалом відповідають глобальним тенденціям, але відбуватимуться більш швидкими темпами порівняно з рештою країн світу [3].

Низький рівень народжуваності та збільшення тривалості життя матимуть істотні наслідки для публічних фінансів, особливо для пенсійної системи. За інших рівних умов, скорочення чисельності населення працездатного віку обумовить зменшення кількості платників єдиного соціально внеску. Водночас видатки на соціальний захист літніх людей, зокрема пенсійні видатки, зростатимуть разом із збільшенням частки людей похилого віку.

Система добровільного накопичувального пенсійного забезпечення представлена наступними показниками: станом на 30.06.2019 в Державному реєстрі фінансових установ містилася інформація про 62 недержавних 
пенсійних фонди (далі - НПФ) та 22 адміністратори НПФ. Загальна кількість учасників НПФ становила 860,8 тис. осіб, з яких отримали/отримують пенсійні виплати 82,7 тис. осіб. Сума сплачених внесків становила 2,07 млрд грн; 90,5 $\%$ всіх внесків надійшли від роботодавців. Загальна вартість активів НПФ становила 2,89 млрд грн. Розмір пенсійних виплат за цей період становив 878,6 млн грн.

Цілком очевидно, що, за таких масштабів та рівня залучення осіб до добровільних пенсійних програм (7\% від працюючого населення), система добровільного накопичувального пенсійного забезпечення не справляється 3 основною метою - суттєвого доповнення солідарної розподільчої системи на макроекономічному рівні та забезпечення гідного рівня життя після виходу на пенсію.

Для відновлення належного рівня пенсійного забезпечення в Україні необхідним $\epsilon$ впровадження обов'язкового накопичувального пенсійного забезпечення як додаткового елемента пенсійної системи (так званого другого рівня), з метою формування пенсійних накопичень та збільшення сукупного коефіцієнта заміщення як головного індикатора достатності пенсійних виплат.

Функціонування системи загальнообов'язкового накопичувального забезпечення надасть можливість громадянам України отримувати після досягнення пенсійного віку додаткові пенсійні виплати за рахунок внесків до накопичувальної пенсійної системи. Протягом всього періоду накопичення буде здійснюватися інвестування внесків. Накопичення кожної особи підлягають обліку на індивідуальному накопичувальному пенсійному рахунку такої особи та можуть бути успадковані.

Запровадження системи загальнообов'язкового накопичувального забезпечення поступово приводитиме до підвищення рівня соціального захисту людей пенсійного віку, залучення потужного внутрішнього довгострокового інвестиційного ресурсу, що сприятиме збільшенню інвестицій в національну економіку.

27 грудня 2019p. група депутатів від політичної партії "Слуга народу" внесла до Верховної Ради проект закону №2683 про загальнообов’язкове накопичувальне пенсійне забезпечення.[3] Законопроектом передбачається встановити обов'язкову участь у системі накопичувального пенсійного забезпечення всіх категорій працюючих осіб до досягнення ними пенсійного віку та залучення роботодавців до сплати пенсійних внесків на паритетних засадах Так, роботодавці сплачуватимуть $2 \%$ від розміру заробітної плати працівників, а учасники системи (працюючі особи) сплачуватимуть внески у розмірі 1 відсоток від заробітної плати (доходу). За бажанням працівника, розмір його самостійних внесків може бути збільшено. Роботодавець зобов’язаний пропорційно доповнювати внески працівника власними внесками в розмірі до 5\% від суми заробітної плати такого працівника.

Законопроектом пропонується встановити, що кошти накопичувальної 
системи $є$ власністю учасників системи (осіб, 3 заробітної плати яких здійснюються відрахування) у розмірі, накопиченому на їх індивідуальних накопичувальних пенсійних рахунках, а у випадку смерті особи право власності на пенсійні заощадження переходять до їі спадкоємців.

Законопроектом запропонована комбінована модель функціонування системи накопичувального пенсійного забезпечення, яка передбачає акумулювання внесків у Пенсійному казначействі, залучення Центрального адміністратора для здешевлення та консолідації послуг з адміністрування персоніфікованих рахунків учасників Пенсійного казначейства, а також в недержавних пенсійних фондах, допущених до діяльності у другому рівні пенсійної системи шляхом авторизації.

Управління активами коштів Пенсійного казначейства буде здійснюватися компаніями $з$ управління активами, допущеними до діяльності в другому рівні пенсійної системи шляхом авторизації.

Зберігання активів Пенсійного казначейства буде здійснюватися банками-зберігачами, допущеними до діяльності в другому рівні пенсійної системи шляхом авторизації.

Авторизація компаній з управління активами, зберігачів, недержавних пенсійних фондів, адміністраторів та страхових компаній буде здійснюватись шляхом включення їх до Реєстру авторизованих суб’єктів системи накопичувального пенсійного забезпечення за умови відповідності таких суб’єктів, встановленим законом вимогам.

Учасник системи повинен обрати пенсійний портфель (консервативний, збалансований, або динамічний) авторизованої компанії з управління активами Пенсійного казначейства, або авторизований недержавний пенсійний фонд.

При цьому свій вибір учасник системи здійснює в електронному кабінеті учасника системи на сайті Центрального адміністратора або подає заяву встановленого зразка до органів Центрального адміністратора.

При цьому внески учасників системи, які не визначились зі своїм вибором, підлягають автоматичному розподілу між пенсійними портфелями, управління активами яких здійснюється авторизованими компаніями 3 управління активами, 3 якими Радою Пенсійного казначейства укладені договори.

Учасник системи матиме право змінити пенсійний портфель, або обрати авторизований недержавний пенсійний фонд.

Законопроектом передбачено, що учасники системи будуть мати право на отримання за рахунок коштів системи накопичувального пенсійного забезпечення одноразових виплат, прискорених виплат, програмних виплат, довічних пенсій.

Також, Законопроектом передбачено внесення змін до низки законодавчих актів України 3 метою передбачення відповідальності за порушення законодавства у системі загальнообов’язкового накопичувального 
забезпечення, узгодження норм Законопроекту 3 нормами чинного законодавства.

В кінцевому підсумку, основною метою Законопроекту є створення накопичувальної пенсійної системи, яка повинна бути:

- простою та зрозумілою для учасників системи, включаючи однакові умови доступу для всіх категорій осіб, які є учасниками системи;

- дешевою, включаючи заходи 3 консолідації певних функцій та обмеження максимальних розмірів витрат, що відшкодовуються за рахунок активів учасників;

- надійною, що передбачає встановлення принципів обережного інвестування та встановлення дієвих систем управління ризиками при проведенні операцій з пенсійними активами.

Реалізація положень законопроекту потребуватиме додаткових витрат iз Державного бюджету України на створення та забезпечення функціонування Пенсійного казначейства [4].

В рамках реалізації проекту пропонується впровадити механізм комплексної системи персоніфікованого обліку учасників - громадян України та забезпечити ефективний контроль за напрямами інвестицій пенсійних коштів. 3 цією метою передбачається створення дворівневої вертикально орієнтованої моделі управління коштами учасників системи накопичувального пенсійного забезпечення. Централізоване адміністрування даних щодо пенсійних внесків, передбачене законопроектом, передбачає встановлення дієвих механізмів розподілу пенсійних коштів та надання громадянам доступу до інформації щодо стану заощаджень на міжрегіональному рівні та здешевлення супроводжуючих послуг внаслідок централізації послуг 3 адміністрування та вибору суб’єкта за встановленими жорсткими вартісними умовами щодо таких послуг.

Пенсійне казначейство призначене в першу чергу для осіб, яким з певних причин буде важко визначитись 3 вибором того чи іншого фінансового інституту (авторизованої компанії з управління активами або авторизованого недержавного пенсійного фонду) та який на конкурентних засадах залучає інших суб'єктів ринкової інфраструктури (компанії з управління активами та зберігачі) для забезпечення ефективного інвестування та захисту коштів учасників.

Пенсійне казначейство є юридичною особою публічного права, яка створюється Кабінетом Міністрів України та функціонує в організаційноправовій формі установи, яка не має на меті отримання прибутку.

Кабінет Міністрів України передає Пенсійному казначейству грошові кошти та майно для забезпечення його створення та початку функціонування. Такі грошові кошти та майно не є коштами учасників системи.

Для забезпечення управління та здійснення контролю за поточною діяльністю Пенсійного казначейства утворюється Рада Пенсійного 
казначейства. До складу Ради Пенсійного казначейства входять п’ять осіб, які призначаються шляхом обрання за результатами конкурсу.

Адміністративний офіс $\epsilon$ виконавчим органом Ради Пенсійного казначейства, призначеним для організаційно-технічного забезпечення діяльності Пенсійного казначейства.

Джерелами формування бюджету Пенсійного казначейства є кошти учасників системи загальнообов'язкового накопичувального пенсійного забезпечення в межах розміру, передбаченого законопроектом (не більше $0,1 \%$ від вартості активів учасників системи загальнообов'язкового накопичувального пенсійного забезпечення) та кошти Державного бюджету в перші 2 роки з моменту створення Пенсійного казначейства.

Висновки. Упровадження обов'язкової накопичувальної системи та створення Пенсійного казначейства в Україні $\epsilon$ нагальною потребою сьогодення, адже солідарна система $\epsilon$ інституційно застарілою та економічно неефективною. 3 урахуванням демографічних тенденцій до постаріння населення України збереження солідарної системи призведе до значного навантаження на державний бюджет. Отже реформа пенсійної системи, окрім фінансово-економічного результату, має яскраво виражену соціальну спрямованість, оскільки йдеться про надання гідного матеріального забезпечення мільйонам пенсіонерів.

\section{Jimeamypa:}

1.Романенко Є.О. Місце та роль Державної комісії з регулювання ринків фінансових послуг України в регулюванні діяльності недержавних пенсійних фондів // Економіка i регіон. Науковий вісник Полтавського національного технічного університету імені Юрія Кондратюка. №1(2) 2004, с.163-166.

2.Про загальнообов’язкове державне пенсійне страхування. Закон України від 9 липня 2003 року № 1058-IV.

3. Проект Закону про загальнообов'язкове накопичувальне пенсійне забезпечення. №2683 від 27.12.2019. http://w1.c1.rada.gov.ua/pls/zweb2/webproc4_1?pf3511=67794

4. Пояснювальна записка до проекту Закону України «Про загальнообов’язкове накопичувальне пенсійне забезпечення» http://w1.c1.rada.gov.ua/pls/zweb2/webproc4_1?pf3511=67794

\section{References:}

1.Romanenko, Ye.O. (2004). Mistse ta rol Derzhavnoi komisii z rehuliuvannia rynkiv finansovykh posluh Ukrainy v rehuliuvanni diialnosti nederzhavnykh pensiinykh fondiv [Place and role of the State Commission for Regulation of Financial Services Markets of Ukraine in Regulation of Non-State Pension Funds Activity]. Ekonomika i rehion. Naukovyi visnyk Poltavskoho natsionalnoho tekhnichnoho universytetu imeni Yuriia Kondratiuka - Economy and Region. Scientific Bulletin of the Yuri Kondratyuk National Technical University,1(2), 163-166 [in Ukrainian].

2. Zakon Ukrainy "Pro zahalnooboviazkove derzhavne pensiine strakhuvannia" : vid 9 lypnia 2003 roku, № 1058-IV [Law of Ukraine “On compulsory state pension insurance” from July 9, 2003, № 1058-IV]. (n.d.). zakon.rada.gov.ua. Retrieved from https://zakon.rada.gov.ua/laws/show/1058-15 [in Ukrainian]. 
3. Proekt Zakonu "Pro zahalnooboviazkove nakopychuvalne pensiine zabezpechennia" : vid 27.12.2019, № 2683 [Draft Law “On Compulsory Cumulative Pension Provision” from December 27, 2019, № 2683]. (n.d.). zakon.rada.gov.ua. Retrieved from http://w1.c1.rada.gov.ua/pls/zweb2/webproc4_1?pf3511=67794 [in Ukrainian].

4. Poiasniuvalna zapyska do proektu Zakonu Ukrainy «Pro zahalnooboviazkove nakopychuvalne pensiine zabezpechennia» [Explanatory Note to the Draft Law of Ukraine On Compulsory Compulsory Retirement Pension]. (n.d.). zakon.rada.gov.ua. Retrieved from http://w1.c1.rada.gov.ua/pls/zweb2/webproc34?id=\&pf3511=67794\&pf35401=516389 [in Ukrainian]. 